\title{
Reproduction of the catfish Iheringichthys labrosus (Lütken) (Pisces, Siluriformes) in Furnas reservoir, Minas Gerais, Brazil
}

\author{
José Enemir dos Santos ${ }^{1,2}$, Nilo Bazzoli 1, 2, Elizete Rizzo ${ }^{2}$ \& Gilmar Bastos Santos ${ }^{1}$ \\ 1 Programa de Pós-graduação em Zoologia de Vertebrados, Pontifícia Universidade Católica de Minas Gerais. Avenida Dom \\ José Gaspar 500, 30535-610 Belo Horizonte, Minas Gerais, Brasil. E-mail: bazzoli@pucminas.br \\ 2 Departamento de Morfologia, Instituto de Ciências Biológicas, Universidade Federal de Minas Gerais. Caixa Postal 486, \\ 30161-970 Belo Horizonte, Minas Gerais, Brasil. E-mail: icitio@mono.icb.ufmg.br
}

\begin{abstract}
The reproductive biology of Iheringichthys labrosus (Lütken, 1874) was studied in Furnas reservoir, Minas Gerais, Brazil. The fishes, 323 males and 817 females, were captured bimonthly from August 1993 to July 1994 by using gill nets with 3-10 cm mesh size. Gonadal maturation of the specimens was analyzed through macro and microscopical characteristics of the gonads. The secretory activity of the tubules of the caudal region of the testis was analyzed during the maturational testicular cycle. Females and males were in reproductive activity throughout the year in the reservoir. The peak of advanced maturation/mature stages occurred from October to January and of spawned/spent from February to May. The spawning of I. labrosus was identified as fractional or multiple type: occurring in the reservoir or in tributaries around it. The oocyte development of the species was asynchronous as different clusters of oocytes occurred simultaneously in the ovarian parenchyma. The epithelium of the tubules of the caudal region of the testis was in high secretory activity during advanced maturation/mature stage and this activity was absence in resting. The gonadosomatic index followed gonadal maturation, and the hepatosomatic index of females was lowest in advanced maturation/mature probably due the contribution of the liver in the vitellogenesis. The variations of the stomach repletion index, coelomic fat and condition factor indicated that the feeding activity was reduced and that the energetic reserves were consumed during the reproductive period. KEY WORDS. Gonadal maturation, Pimelodidae, spawning.
\end{abstract}

RESUMO. A biologia reprodutiva de Iheringichthys labrosus (Lütken, 1874) foi estudada no reservatório de Furnas, Minas Gerais, Brasil, utilizando-se técnicas biométricas, macroscópicas e microscópicas. Capturaram-se, bimestralmente, 323 machos e 817 fêmeas, utilizando-se redes de emalhar no período de agosto de 1993 a julho de 1994. A atividade secretora dos túbulos da região caudal dos testículos foi analisada durante o período reprodutivo. Machos e fêmeas encontravam-se em atividade reprodutiva durante todo ano com pico de maturação avançada / maduro de outubro a janeiro de desovado/espermiado de fevereiro a maio. $O$ longo período de desova e a alta freqüência de fêmeas parcialmente desovadas indicaram que a espécie tem desova do tipo parcelado, com desenvolvimento assincrônico dos ovócitos. A espécie desova no reservatório e/ou em tributários nas suas proximidades. O epitélio dos túbulos da região caudal dos testículos apresentou alta atividade secretora durante o estádio maturação avançada/maduro, estando essa atividade ausente no estádio de repouso. $O$ índice gonadossomático acompanhou a maturação das gônadas e o índice hepatossomático apresentou-se mais baixo na maturação avançada/maduro, sugerindo transferências de substâncias hepáticas para os ovários. As variações dos índices de repleção do estômago, de gordura celômica e o fator de condição indicaram que os peixes alimentam-se menos e consomem reservas graxas no período reprodutivo. PALAVRAS CHAVE. Desova, maturação gonadal, Pimelodidae.

Reproductive cycle and gametogenesis are important parameters in understanding the reproduction of native fish species, and to the establishment conservation programs (BAzzoli \& GodinHo 1991).

A fish's spawning type indicates the frequency of mature oocytes released within the same reproductive period (VAzzoler 1996). In fractional or multiple spawning, oocyte development is asynchronous, maturation occurs in many clusters and the spawning takes place for a long period; this is a common strategy of many species from lentic environments (BAzzoli 2003). In total spawning, oocyte development is groupsynchronous, maturation occurs in only two clusters and spawning occurs over a short period of time: being characteristic of species from lotic environments (SATO et al. 2003). 
The parameters or biological indexes of reproduction show the way in which fish use environmental/energetic resources. The gonadosomatic index is a good indicator of reproductive activity, then being used in determining fish reproductive cycle stages (DE Vlaming et al.1982). Variations in the hepatosomatic index of teleost are related to the liver capacity to store glycogen, physiological conditions, reproduction activity, feeding habit and food availability (TAVARES-Dias et al. 2000). In tropical environments, feeding plays a fundamental role in determining reproductive rhythm (VAzzoler \& Menezes 1992). Variations in fish coelomic fat level may be related to their reproductive cycle as well as the river or reservoir hydrologic cycle (Lamas \& GodinHo 1996). The Fulton condition factor may indicate the period of time in which gonadal maturation occurs and it is used as a measure of fish physiological state, allowing comparison between two or more populations that are found in different ecological conditions (NiKolski 1963, BARBIERI et al. 1996).

The Siluriformes order shows wide geographic distribution, occurring principally in South America, Africa and Southeast Asia, with approximately 34 families, 412 genuses and over 2400 species (Nelson 1994, De Pinna 1998). The mandi-beiçudo, Iheringichthys labrosus (Lütken, 1874), belongs to the family Pimelodidae and occurs along the entire, Prata river basin being abundant in several reservoirs (Burges 1989). A recent study on the reproductive system of $I$. labrosus showed fringed testis and a peculiar morphofunctional organization with three regions: a spermatogenic cranial, a secretory caudal and a transitional medial with spermatogenic and secretory activities (SANTOS et al. 2001).

Despite of its wide geographic distribution, only a few studies on I. labrosus have been conducted, mainly concerning in its reproductive dynamics. At the Itaipú reservoir, Paraná state, Brazil, studies on I. labrosus showed that this species does not migrate nor exhibit parental care of its offspring and it spawns in the reservoir (Agostinho \& Júlio Jr. 1999). In Furnas reservoir, I. labrosus is the second most captured species, representing $18 \%$ of the total fish biomass (SAntos \& Formagio 2000).

Taking in account the importance of $I$. labrosus in ecology of the Furnas reservoir, the objective of this presents study was carried is to evaluate the reproductive dynamics through macro and microscopical analysis and the relationship of the biological indexes with the reproductive cycle.

\section{MATERIALS AND METHODS}

\section{Animals}

Adult specimens of I. labrosus, comprising 323 males and 817 females were captured bimonthly from August 1993 to July 1994, by using gill nets with $3-10 \mathrm{~cm}$ mesh size, in the Furnas reservoir $\left(20^{\circ} 40^{\prime} \mathrm{S}, 46^{\circ} 19^{\prime} \mathrm{W}\right)$, state of Minas Gerais, Southeastern Brazil. The specimens were fixed in $10 \%$ formaldehyde for macroscopical analyses.

\section{Gonads analyses}

Fragments of gonads were fixed in Bouin's fluid for 8-12 hours, embedded in paraffin and glycol-methacrilate plastic resin, sectioned at 3-5 $\mu \mathrm{m}$ and stained with hematoxilin-eosin for histological analyses, under light microscopy (JUNQUEIRA \& JUNQUEIRA 1983).

Morphological characteristics of the spermatogenic lineage cells were determined according to SANTOs et al. (2001) and the oogenesis cells were classified based on features observed by BAzzoLI (2003).

\section{Reproductive cycle and spawning}

The reproductive cycle and spawning type were determined through macro and microscopic characteristics of the gonads as well as the frequency distribution of the reproductive cycle stages.

\section{Biological indexes}

From each specimen we measured standard length (SL); and the weights of the body (BW), of the gonads (GW), of the liver (LW), of the stomach (SW) and of the coelomic fat (CFW). The following biological parameters were determined for each stage of the reproductive cycle: gonadosomatic index (GSI = GW/ BW $x$ 100), hepatosomatic index (HSI = LW/BW x 100), stomach repletion index $(S R I=S W / B W \times 100)$, coelomic fat index $(\mathrm{CFI}=\mathrm{CFW} / \mathrm{BW} \times 100)$ and Fulton condition factor $(\mathrm{K}=(\mathrm{BW}$ GW)/SL3 x 100) (le Cren 1951, Nikolski 1963, Vazzoler 1996).

\section{Statistical analysis}

A one-way analysis of variance (ANOVA) followed by Duncan's test $(\mathrm{p}<0.05)$ was performed to compare the means of the biological indexes for stages of the reproductive cycle.

\section{RESULTS}

\section{Gonadal maturation}

The gonads of I. labrosus were paired organs, related to the swimblader cranially and to the kidneys caudally. They presented macro and microscopical variations during the different reproductive cycle stages:

Stage 1 (resting). The testes showed fringes with a reduced size. In the cranial region, the seminiferous tubules contained only spermatogonia in its wall, and an occluded lumen (Fig. 1). In the caudal region, the tubules were open and there was no secretion (Fig. 6). The ovaries were translucent, without evident vascularization and contained initial and advanced perinucleolar oocytes (Fig. 8).

Stage 2 (initial maturation). The testes increased in volume and the fringes were a milky white colour. In the wall of the seminiferous tubules we identified cysts of spermatogenic cells in different developmental phases (Fig. 2). In the cranial region, few spermatozoa were in the lumen, and little secretion occurred on the caudal region. The ovaries were yellowish, and also increased in volume, contained initial and advanced perinucleolar oocytes and some previtellogenic oocytes (Fig. 9). 

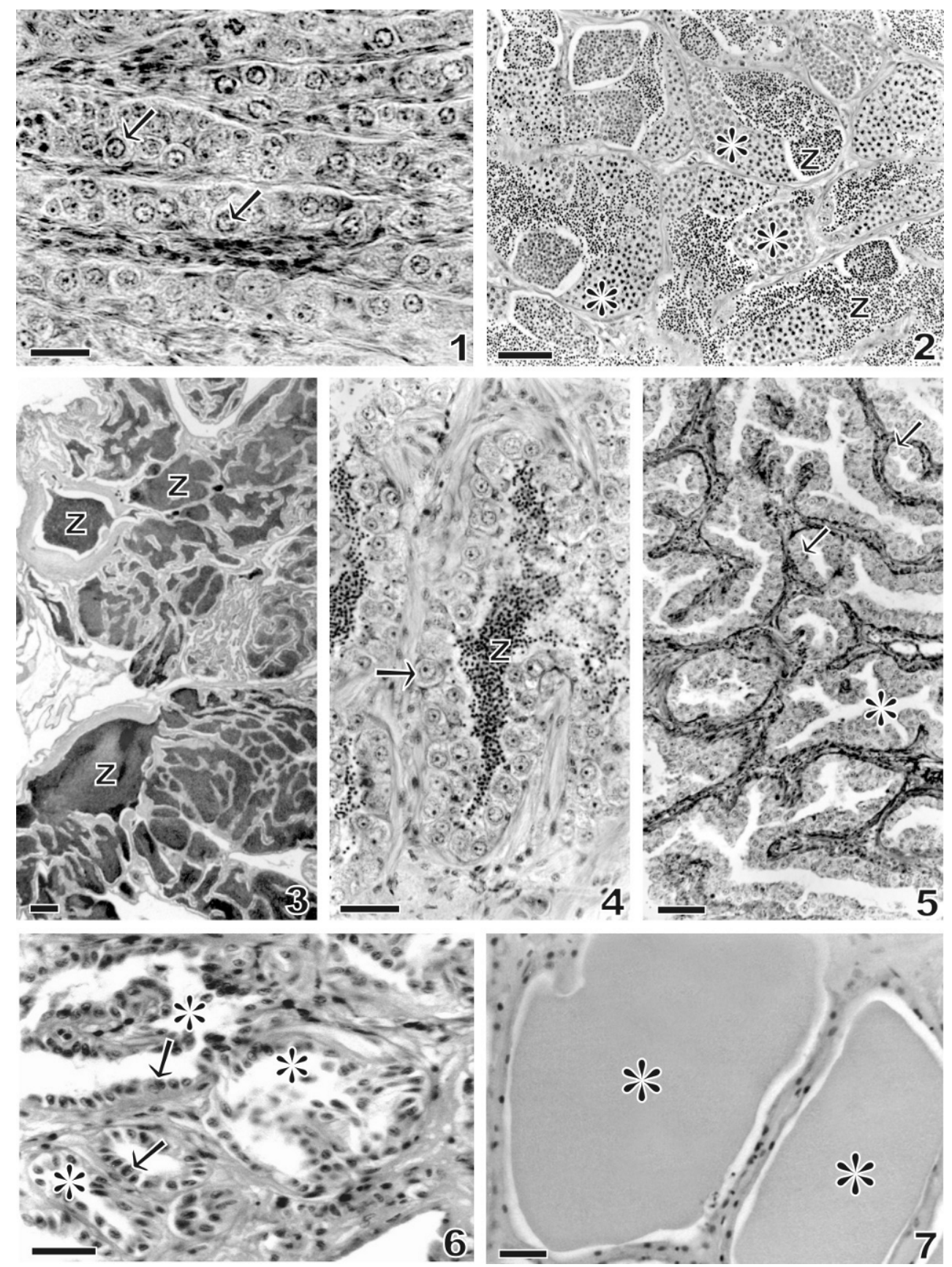

Figure 1-7. Histological sections of testis of $I$. labrosus stained with hematoxilin-eosin, in different reproductive cycle stages: (1) resting stage showing seminiferous tubules with an occluded lumen and spermatogonia surrounded by connective tissue (arrow); (2) initial maturation stage containing spermatogenic lineage cell in different development phases $\left({ }^{*}\right)$ and few spermatozoa $(Z)$ inside the lumen of the seminiferous tubules; (3) advanced maturation/mature stage with the lumen of the seminiferous tubules and spermatic ducts filled with spermatozoa (Z); (4) partially spent stage showing seminiferous tubules with spermatogonia (arrow) and an opened lumen with few spermatozoa (Z); (5) totally spent stage showing seminiferous tubules with an open lumen $\left({ }^{*}\right)$ and epithelium containing only spermatogonia (arrow); (6) caudal region of resting testis: tubule walls consisting of secretory cells only (arrow); open lumem with no secretion ( $\left.{ }^{*}\right)$; (7) caudal region of advanced maturation/mature testis: accumulation of secretion in lumen ( ${ }^{*}$ ). Scale: $200 \mu \mathrm{m}$. 

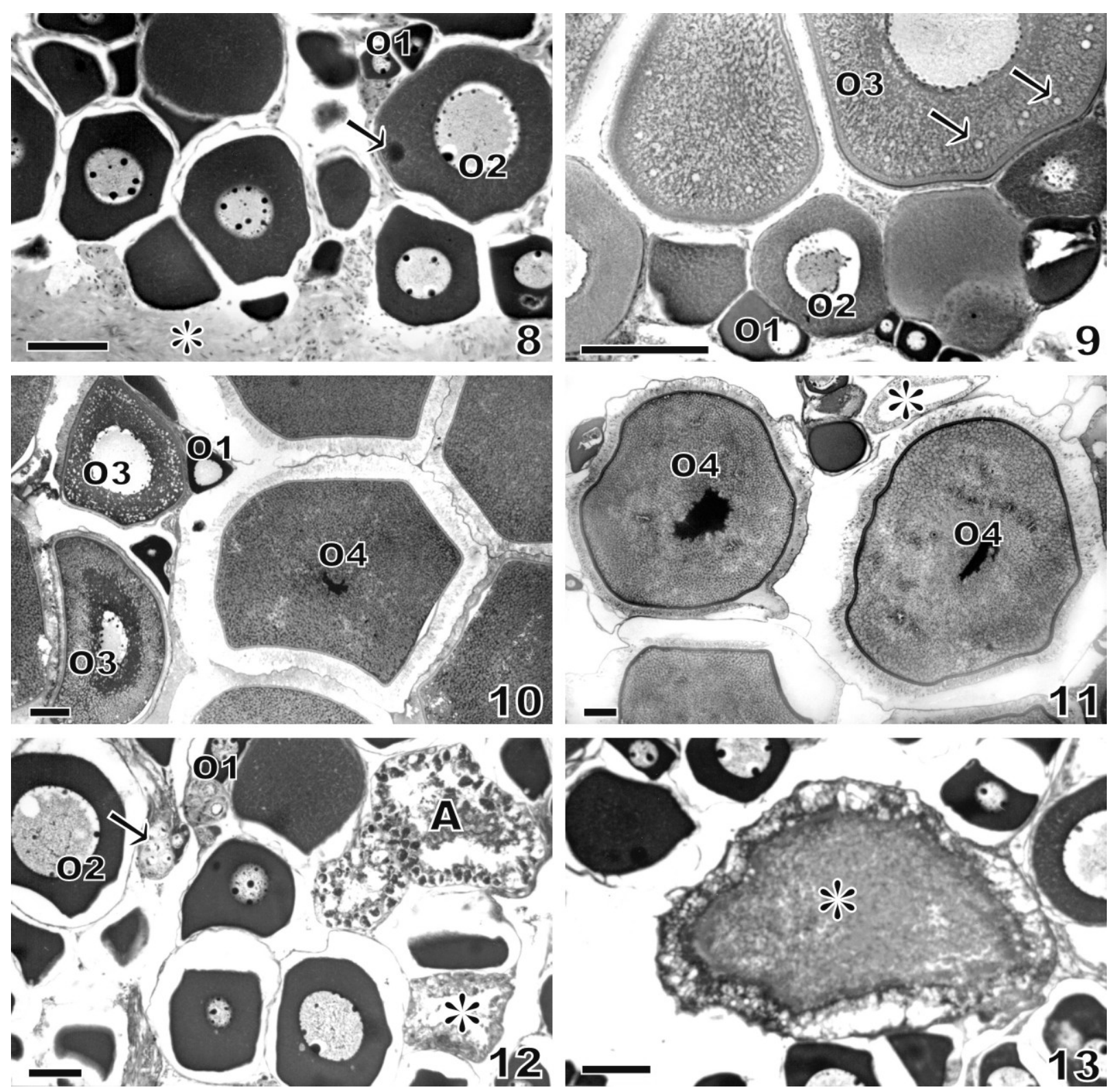

Figure 8-13. Histological sections of ovaries of $I$. labrosus stained with hematoxilin-eosin, in different reproductive cycle stages: (8) resting stage presenting initial perinucleolar oocytes (O1), advanced perinucleolar oocytes (O2) with yolk nucleus (arrow) and tunica albuginea $\left({ }^{*}\right)$; (9) initial maturation stage containing O1, O2 and previtellogenic oocytes (O3) with cortical vesicles (arrow); (10) advanced maturation/mature stage presenting $01, \mathrm{O} 2, \mathrm{O} 3$ and vitellogenic oocytes (O4); (11) partially spawned stage presenting postovulatory follicle $\left(^{*}\right)$ and $\mathrm{O} 4 ;(12)$ totally spawned stage showing atretic follicle (A), postovulatory follicle $\left({ }^{*}\right), 01, \mathrm{O} 2$ and oogonia (arrow); (13) detail of atretic follicle showing hypertrophied follicular layer and yolk liquefaction $\left({ }^{*}\right)$. Scale: $100 \mu \mathrm{m}$.

Stage 3 (advanced maturation/mature). Voluminous testes showed prominent milky white fringes. In the cranial region, the lumen of the seminiferous tubules and spermatic ducts were filled with spermatozoa (Fig. 3), and there was abun- dant secretion accumulated into the lumen of the tubules of the caudal region (Fig. 7). Yellowish and voluminous ovaries presented oocytes visible to the naked eye. Histological analyses showed predominance of vitellogenic oocytes (Fig. 10).

Revista Brasileira de Zoologia 21 (2): 193-200, junho 2004 
Stage 4A (partially spent/spawned). Milky white color testes showed flaccid fringes with reduced volume. In the cranial region, the lumen of the seminiferous tubules was open and contained few spermatozoa (Fig. 4), and secretion was still observed in the caudal region. Flaccid ovaries with hemorrhagic areas contained oocytes in all development phases and postovulatory follicles (Fig. 11).

Stage 4B (totally spent/spawned). Flaccid testes showed considerable reduction in volume and small fringes. The lumen of the seminiferous tubules of the cranial region and spermatic duct were open and empty or with residual spermatozoa (Fig. 5). Little acidophilic secretion was observed in the caudal region. Flaccid hemorrhagic ovaries contained initial and advanced perinucleolar oocytes as well as atretic vitellogenic follicles (Figs 12 and 13).

Reproductive cycle and biological parameters. Fish in reproductive activity (stages 2, 3 and 4) occurred all year around. Peaks of advanced maturation/mature were observed from October to January (Tabs I and II). Spent and spawned fish (stages 4A and 4B) were captured throughout the year with peaks from February to May. Fish in the resting stage were predominant from April to July.

The GSI of males and females reached the highest values in stage 3 , while $\mathrm{K}$ showed its highest values in stages 1 and 2 , gradually decreasing in the following stages. The HSI of females reached the lowest values in stage 3 , however, in males it did not show any difference between stages. The CFI of males and females showed the lowest values in stage 3 (Tabs III and IV).

Spawning. The presence of spawned females during the whole reproductive cycle indicated that I. labrosus exhibits fractioned or multiple spawning with asynchronous oocyte development.

\section{DISCUSSION}

The morphofunctional organization of the male reproductive system of Siluriformes is variable between species. Some species may present testis with digitiform fringes with or without secretory caudal region; accessory organ like a seminal vesicle was also seen in some Siluriformes (Lorr et al. 1989). In I. labrosus testes are fringed in all their extension, with cranial spermatogenic region and caudal secretory region (SANTOS et al. 2001). Conversely, ovaries of this species presented morphological characteristics similar to the majority of teleosts.

In the present study we established five reproductive cycle stages in I. labrosus, based on morphological characteristics and distribution of gametogenic cells. The variations of the secretory activity of the cells in tubules of the caudal region of the testis were also observed during the maturational cycle. Seasonal alterations in secretory activity of the seminal vesicles in relation to testis cycle have already been described in few spe- cies: Mystus tengara (Hamilton, 1822) (RAstogI 1969), Heteropneustes fossilis (Bloch, 1794) (NAYYAR \& SUndararaj 1970) and Clarias batrachus (Linnaeus, 1748) (SINGH \& Joy 1999).

For both females and males, peak GSI values were recorded in the advanced maturation/mature stage, with GSI decreasing in the spawned/spent stage. In fact, increasing GSI values are associated with maturation, whereas decreasing values are related to gamete extrusion and/or reabsorption (Agostinho et al. 1992). In females, the highest values for IHS during stages 2 and 3 may be related to the synthesis of vitelogenina in the liver (Selman \& Wallace 1989). However, no significant differences were found among the values for IHS (ANOVA) in the various reproductive cycle stages of the males, demonstrating that the liver does not influence testes maturation (SсотT \& PANKhurst 1992). The highest mean values for SRI in females were observed during the spawned stage, indicating that the species found better feeding conditions after the reproductive cycle, probably to compensate for spawning losses (LE CREN 1951). During the advanced maturation/ mature stage, the feeding activity had been reduced due to the compression of the digestive organs by the gonads, especially in females, and after the spawning feeding activity began again (SLotTe 1999). Males and females of I. labrosus presented the lowest values for CFI in the advanced maturation/mature stage, suggesting that the fish consume their lipid reserve during this period, which has also been reported by BAzzoli et al. (1998). Contrarily, GodinHo et al. (1997) observed the presence of coelomic fat in advanced maturing and spawned females of Plagioscion squamosissimus (Heckel, 1840), indicating that vitellogenesis proceeds without depleting the lipid reserve. The lowest values for $\mathrm{K}$ in I. labrosus were registered in the advanced maturation/mature and spent/spawning stages, due to reduction of feeding activity and the consumption of lipid reserve during the reproductive period (ORTAz 1997).

In conclusion, I. labrosus spawned almost throughout the year in the Furnas Reservoir or in small tributaries around it. The epithelium of the tubules of the caudal region of the testis was in high secretory activity during advanced maturation/mature stage and this activity was absence in the resting stage. The species showed fractional or multiple spawning with peaks of advanced maturation/mature from October to January and it spawned from February to May, similar to Pimelodus maculatus Lacépède, 1803 in the same reservoir (BAzzoli et al. 1997).

\section{ACKNOWLEDGEMENTS}

The authors are grateful to: the staff of the Furnas Hydrobiology and Fishery Station (Furnas Centrais Elétricas S/A) for their assistance during the collection of the fish; to the Brasilian Research Foundations: CNPq, FAPEMIG and FIP-PUC Minas for financial support; and to Dr Robert J. Young for the suggestions on the English version.

Revista Brasileira de Zoologia 21 (2): 193-200, junho 2004 
Table I. Frequency distribution of the reproductive cycle stages for males of I. labrosus, in the Furnas reservoir from August 1993 to July 1994.

\begin{tabular}{|c|c|c|c|c|c|c|c|c|c|c|c|}
\hline \multirow{2}{*}{ Bimester/Year } & \multicolumn{2}{|c|}{1} & \multicolumn{2}{|c|}{2} & \multicolumn{2}{|c|}{3} & \multicolumn{2}{|c|}{$4 \mathrm{~A}$} & \multicolumn{2}{|c|}{$4 B$} & \multirow{2}{*}{ Total } \\
\hline & $\mathrm{Fa}$ & $\operatorname{Fr}(\%)$ & $\mathrm{Fa}$ & $\operatorname{Fr}(\%)$ & $\mathrm{Fa}$ & $\operatorname{Fr}(\%)$ & $\mathrm{Fa}$ & $\operatorname{Fr}(\%)$ & $\mathrm{Fa}$ & $\operatorname{Fr}(\%)$ & \\
\hline Aug-Sep/93 & 5 & 6.25 & 29 & 36.25 & 35 & 43.75 & 4 & 5.00 & 7 & 8.75 & 80 \\
\hline Oct-Nov/93 & - & - & 5 & 4.95 & 88 & 87.12 & 6 & 5.94 & 2 & 1.98 & 101 \\
\hline Dez/93-Jan/94 & - & - & 1 & 2.00 & 45 & 90.00 & 1 & 2.00 & 3 & 6.00 & 50 \\
\hline Feb-Mar/94 & 1 & 2.70 & - & - & 14 & 37.84 & 8 & 21.62 & 14 & 37.84 & 37 \\
\hline Apr-May/94 & 8 & 29.62 & - & - & - & - & 1 & 3.70 & 18 & 66.66 & 27 \\
\hline Jun-Jul/94 & 9 & 32.14 & 6 & 21.42 & - & - & 1 & 3.57 & 12 & 42.85 & 28 \\
\hline Total & 23 & 7.12 & 41 & 12.69 & 182 & 56.36 & 21 & 6.50 & 56 & 17.33 & 323 \\
\hline
\end{tabular}

(1) Resting, (2) initial maturation, (3) advanced maturation/mature, (4A) partially spawned, (4B) totally spawned, (-) not captured.

Table II. Frequency distribution of the reproductive cycle stages of I. labrosus females in the Furnas reservoir from August 1993 to July 1994.

\begin{tabular}{|c|c|c|c|c|c|c|c|c|c|c|c|}
\hline \multirow{2}{*}{ Bimester/Year } & \multicolumn{2}{|c|}{1} & \multicolumn{2}{|c|}{2} & \multicolumn{2}{|c|}{3} & \multicolumn{2}{|c|}{$4 \mathrm{~A}$} & \multicolumn{2}{|c|}{$4 \mathrm{~B}$} & \multirow{2}{*}{ Total } \\
\hline & $\mathrm{Fa}$ & $\mathrm{Fr}(\%)$ & $\mathrm{Fa}$ & $\operatorname{Fr}(\%)$ & $\mathrm{Fa}$ & $\mathrm{Fr}(\%)$ & $\mathrm{Fa}$ & $\operatorname{Fr}(\%)$ & $\mathrm{Fa}$ & $\mathrm{Fr}(\%)$ & \\
\hline Aug-Sep/93 & 27 & 13.37 & 68 & 33.66 & 74 & 36.63 & 18 & 8.91 & 15 & 7.43 & 202 \\
\hline Oct-Nov/93 & 1 & 0.41 & 15 & 6.15 & 207 & 84.84 & 15 & 6.15 & 6 & 2.45 & 244 \\
\hline Dez/93-Jan/94 & 10 & 9.35 & 2 & 1.87 & 84 & 78.50 & 9 & 8.41 & 2 & 1.87 & 107 \\
\hline Feb-Mar/94 & 7 & 5.88 & - & - & 2 & 1.68 & 29 & 24.38 & 81 & 68.06 & 119 \\
\hline Apr-May/94 & 16 & 24.61 & - & - & - & - & 6 & 9.23 & 43 & 66.16 & 65 \\
\hline Jun-Jul/94 & 64 & 80.00 & 2 & 2.50 & - & - & - & - & 14 & 17.50 & 80 \\
\hline Total & 125 & 15.24 & 87 & 10.60 & 367 & 44.92 & 77 & 9.39 & 161 & 19.71 & 817 \\
\hline
\end{tabular}

(1) Resting, (2) initial maturation, (3) advanced maturation/mature, (4A) partially spawned, (4B) totally spawned, (-) not captured.

Table III. Mean values of gonadosomatic (GSI), hepatosomatic (HSI), stomach repletion (SRI), and coelomic fat (CFI) indices and condition factor (K) for each stage of the reproductive cycle (SRC) of I. labrosus males in the Furnas reservoir, from August 1993 to July 1994.

\begin{tabular}{rrrcccl}
\hline SRC & N & GSI & HSI & SRI & CFI & K \\
\hline 1 & 23 & $0.22 \pm 0.17 \mathrm{~d}$ & $0.57 \pm 0.14 \mathrm{a}$ & $0.69 \pm 0.26 \mathrm{a}$ & $0.65 \pm 0.47 \mathrm{a}$ & $1.43 \pm 0.20 \mathrm{ab}$ \\
2 & 41 & $1.47 \pm 0.80 \mathrm{~b}$ & $0.62 \pm 0.17 \mathrm{a}$ & $0.73 \pm 0.36 \mathrm{a}$ & $0.57 \pm 0.48 \mathrm{a}$ & $1.46 \pm 0.15 \mathrm{a}$ \\
3 & 182 & $2.04 \pm 0.82 \mathrm{a}$ & $0.59 \pm 0.22 \mathrm{a}$ & $0.68 \pm 0.60 \mathrm{a}$ & $0.24 \pm 0.37 \mathrm{~b}$ & $1.34 \pm 0.10 \mathrm{c}$ \\
$4 \mathrm{~A}$ & 21 & $1.04 \pm 0.54 \mathrm{c}$ & $0.58 \pm 0.18 \mathrm{a}$ & $0.79 \pm 0.37 \mathrm{a}$ & $0.58 \pm 1.06 \mathrm{a}$ & $1.36 \pm 0.10 \mathrm{abc}$ \\
$4 \mathrm{~B}$ & 56 & $0.46 \pm 0.32 \mathrm{~d}$ & $0.56 \pm 0.23 \mathrm{a}$ & $0.75 \pm 0.30 \mathrm{a}$ & $0.46 \pm 0.59 \mathrm{ab}$ & $1.38 \pm 0.16 \mathrm{bc}$ \\
\hline
\end{tabular}

$(\mathrm{N})$ number of specimens. Values followed by same letter within the same column are not significantly different. (1) resting; (2) initial ripening; (3) advanced ripening/mature; (4A) partially spent; (4b) totally spent.

Table IV. Mean values of gonadosomatic (GSI), hepatosomatic (HSI), stomach repletion (SRI), and coelomic fat (CFI) indices and condition factor (K) for each stage of the reproductive cycle (SRC) of I. labrosus females in the Furnas reservoir, from August 1993 to July 1994.

\begin{tabular}{rrccccc}
\hline SRC & N & GSI & HSI & SRI & CFI & K \\
\hline 1 & 125 & $0.62 \pm 0.44 \mathrm{~d}$ & $0.63 \pm 0.20 \mathrm{~d}$ & $0.67 \pm 0.24 \mathrm{~b}$ & $0.53 \pm 0.51 \mathrm{a}$ & $1.48 \pm 0.14 \mathrm{a}$ \\
2 & 87 & $1.49 \pm 0.91 \mathrm{c}$ & $0.81 \pm 0.22 \mathrm{a}$ & $0.56 \pm 0.23 \mathrm{c}$ & $0.57 \pm 0.46 \mathrm{a}$ & $1.47 \pm 0.15 \mathrm{a}$ \\
3 & 367 & $4.55 \pm 2.22 \mathrm{a}$ & $0.76 \pm 0.24 \mathrm{ab}$ & $0.46 \pm 0.21 \mathrm{~d}$ & $0.14 \pm 0.27 \mathrm{c}$ & $1.37 \pm 0.10 \mathrm{~b}$ \\
$4 \mathrm{~A}$ & 77 & $1.92 \pm 1.51 \mathrm{~b}$ & $0.72 \pm 0.21 \mathrm{bc}$ & $0.68 \pm 0.30 \mathrm{~b}$ & $0.24 \pm 0.33 \mathrm{bc}$ & $1.39 \pm 0.11 \mathrm{~b}$ \\
$4 \mathrm{~B}$ & 161 & $0.71 \pm 0.27 \mathrm{~d}$ & $0.67 \pm 0.22 \mathrm{dc}$ & $0.77 \pm 0.49 \mathrm{a}$ & $0.31 \pm 0.40 \mathrm{~b}$ & $1.38 \pm 0.12 \mathrm{~b}$ \\
\hline
\end{tabular}

$(\mathrm{N})$ number of specimens. Values followed by same letter within the same column are not significantly different. (1) resting; (2) initial ripening; (3) advanced ripening/mature; (4A) partially spawned; (4b) totally spawned.

Revista Brasileira de Zoologia 21 (2): 193-200, junho 2004 


\section{REFERENCES}

Agostinho, A.A.; H.F. Júlio Jr. \& J.R. Borghetti. 1992. Considerações sobre os impactos dos represamentos na ictiofauna e medidas para sua atenuação. Um estudo de caso: reservatório de Itaipu. Revista Unimar, Maringá, 14 (Suppl): 89-107.

Agostinho, A.A. \& H.F. Júlıo JR. 1999. Peixes da bacia do alto rio Paraná, p. 374-400. In: R.H. Lowe-Mcconnell (Ed.). Estudos ecológicos de comunidades de peixes tropicais. São Paulo, EDUSP, 535p.

Barbieri, G.; S.M. Hartz \& J.R. Verani. 1996. O fator de condição e índice hepatossomático como indicadores do período de desova de Astyanax fasciatus da represa do lobo, São Paulo (Osteichthyes, Characidae). Iheringia, Série Zoologia, Porto Alegre, 81: 97-100.

BAzzolı, N. 2003. Parâmetros reprodutivos de peixes de interesse comercial do rio São Francisco, região de Pirapora, MG, p. 286-300. In: H.P. Godinho \& A.L. Godinho (Ed.). Águas, peixes e pescadores do São Francisco das Minas Gerais. Belo Horizonte, CNPq/PADCT, Editora PUC Minas, 440p.

Bazzoli, N. \& H.P. GodinHo. 1991. Reproductive biology of the Acestrorhynchus lacustris (Reinhardt, 1874) (Pisces: Characidae) from Três Marias reservoir, Brazil. Zoologischer Anzeiger, München, 226 (5/6): 285-297.

Bazzoli, N.; L.C.V. Cangussu; E. Rizzo \& G.B. Santos. 1997. Reprodução e desova de mandis Pimelodus maculatus e Iheringichthys labrosus (Pisces, Pimelodidae) nos reservatórios de Furnas, Marimbondo e Itumbiara. Bios, Belo Horizonte, 5 (5): 7-15.

Bazzoli, N.; T.L. Mesquita; G.B. Santos \& E. Rizzo. 1998. Análise comparativa da reprodução de Astyanax bimaculatus (Pisces: Characidae) nos reservatórios de Furnas, Marimbondo e Itumbiara. Bios, Belo Horizonte, 6 (6): 99-112.

Burgess, W.E. 1989. An atlas of freshwater and marine catfishes a preliminary survey of the Siluriformes. New Jersey, T.F.H. Publications, I+784p.

DE PInna, M.C.C. 1998. Phylogenetic relationships of neotropical Siluriformes (Teleostei: Ostariophysi): historical overview and synthesis of hypotheses, p. 279-330. In: L.R MaLABarba; R.E. Reis; R.P. Vari; Z.M.S. Lucena \& C.A.S. Lucena (Ed.). Phylogeny and Classification of Neotropical Fishes. Porto Alegre, EDIPUCRS, III+603p.

De Vlaming, V.L.; G. Grossman \& F. Chapman. 1982. On the use of the gonosomatic index. Comparative Biochemistry and Physiology, Vancouver, 73A (1): 31-39.

GodinHo, H.P.; G.B. SANTOS \& E.C. Assis. 1997. Some aspects of the reproduction of female corvine fish Plagioscion squamosissimus Heckel, 1840 (Sciaenidae) in a reservoir of Southeastern Brazil. Tropical Freshwater Biology, Benin, 6: 17-26.

JunqueIRA, L.C.U. \& L.M.M.S. JUNQUEIRA. 1983. Técnicas básicas de citologia e histologia. São Paulo, Livraria Santos Editora LTDA, I+121p.

LAMAS, I.R. \& A.L. GodinHo. 1996. Reproduction in the piranha
Serrasalmus spiropleura, a neotropical fish with an unusual pattern of sexual maturity. Environmental Biology of Fishes, Dordrecht, 45: 161-168.

LE CREn, E.D. 1951. The length-weight relationship and seasonal cycle in gonad weight and condition in the perch (Perca fluviatilis). Journal of Animal Ecology, Oxford, 20 (2): 201219.

Loir, M.; C. Cauty; P. Planquette \& P.Y. le Bail. 1989. Comparative study of the male reproductive tract in seven families of South-American catfishes. Aquatic Living Resources, Montrouge, 2: 45-56.

NAYYAR, S.K. \& B.I. SundaraRAJ. 1970. Seasonal reproductive activity in the testes and seminal vesicles of the catfish, Heteropneustes fossillis (Bloch). Journal of Morphology, New York, 130: 207-226.

NeLson, J.S. 1994. Fishes of the world. New York, John Wiley \& Sons, III $+600 p$.

Nikolsky, G.V. 1963. The ecology of fishes. London, Academic Press, I+351p.

Ortaz, M. 1997. Reproductive cycle and reproduction of Creagrurus bolivari (Pisces: Characidae) in Venezuela. Revista de Biologia Tropical, San Jose, 45 (3): 1147-1153.

RASTOGI, R.K. 1969. Seminal vesicles and sperm duct of an Indian catfish, Mystus tengara (Ham.), with particular reference to their seasonal cycle. Acta Anatomica, Basel, 72: 624-639.

SAntos, G.B. \& P.S. Formagio. 2000. Estrutura da ictiofauna dos reservatórios do rio Grande, com ênfase no estabelecimento de peixes piscívoros exóticos. Informe Agropecuário, Belo Horizonte, 21 (203): 98-106.

Santos, J.E.; N. Bazzoli; E. Rizzo \& G.B. Santos. 2001. Morphofunctional organization of the male reproductive system of the catfish Iheringichthys labrosus (Lütken, 1874) (Siluriformes: Pimelodidae). Tissue \& Cell, Essex, 33 (5): 533-540.

Sato, Y.; N. Fenerich-Verani; A.P.O. Nuner; H.P. Godinho \& J.R. Verani. 2003. Padrões reprodutivos de peixes da bacia do São Francisco, p. 224-268. In: H.P. Godinho \& A.L. Godinho (Ed.). Águas, peixes e pescadores do São Francisco das Minas Gerais. Belo Horizonte, CNPq/PADCT, Editora PUC Minas, 440p.

ScotT, S.G. \& N.W. PANKhuRst. 1992. Interannual variation in the reproductive cycle of the New Zealand snapper Pagrus auratus (Bloch \& Schneider) (Spariidae). Journal of Fish Biology, London, 41: 685-696.

Selman, K. \& R.A. Wallace. 1989. Cellular aspects of oocyte growth in teleosts. Zoological Science, London, 6: 211-231.

Slotte, A. 1999. Differential utilization of energy during wintering and spawning migration in Norwegian springspawning herring. Journal of Fish Biology, London, 54: 338-335.

SINGH, M.S. \& K.P. Joy. 1999. Annual correlative changes in some biochemical contents of seminal vesicle and testis in catfish Clarias batrachus (L). Zoological Science, London, 16 (2): 345-356.

Revista Brasileira de Zoologia 21 (2): 193-200, junho 2004 
Tavares-Dias, M.; M.L. Martins \& F.R. Moraes. 2000. Relação hepatosomática e esplenosomática em peixes teleósteos de cultivo intensivo. Revista Brasileira de Zoologia, Curitiba, 17 (1): 273-281.

VAzzoler, A.E.M. 1996. Biologia da reprodução de peixes teleósteos: teoria e prática. Maringá, EDUEM, 169p. VAzzoler, A.E.A.M. \& N.A. Menezes. 1992. Síntese de conhecimentos sobre o comportamento reprodutivo dos Characiformes da América do Sul (Teleostei, Ostariophysi). Revista Brasileira de Biologia, São Paulo, 52 (4): 627-640.

Received in 25.VII.2003; accepted in 29.IV.2004.

Revista Brasileira de Zoologia 21 (2): 193-200, junho 2004 